\title{
Tomasz Bąkowski
}

Uniwersytet Gdański

tb@prawo.ug.edu.pl

ORCID: 0000-0002-93-63-2124

https://doi.org/10.26881/gsp.2020.2.02

\section{Pod „brandem” k.p.a. i poza nim}

\section{Wprowadzenie}

Już sam fakt posiadania przez kodeks postępowania administracyjnego' statusu najstarszej z obecnie obowiązujących w polskim porządku prawnym regulacji kodeksowej w sposób naturalny skłania do podejmowania wielowątkowych refleksji oraz dokonywania ocen co do jej przydatności, aktualności oraz efektywności, zarówno z dzisiejszej perspektywy, to jest 60 lat od dnia jej uchwalenia, jak i z punktu widzenia uregulowań obowiązujących w różnych przedziałach czasowych ostatnich sześciu dekad. Jednym z istotnych aspektów, przy czym nie tyle od strony samej procedury stosowania norm prawa administracyjnego, ale z perspektywy rozwiązań legislacyjnych, jest normatywna zawartość k.p.a., która w ciągu tego czasu podlegała wielu interesującym przeobrażeniom.

Rzeczą niezbyt odkrywczą, acz wartą podkreślenia jest to, że k.p.a. na tle pozostałych regulacji administracyjnoprawnych, w tym zwłaszcza materialnoprawnych, cechuje się względną stabilnością, a co za tym idzie, także i trwałością przyjętych rozwiązań. Niewątpliwy wpływ na ową względną trwałość ma w przeważającej mierze procesowy charakter kodeksowych norm. Niemniej jednak wypada odnotować, że 60-letni kodeks był nowelizowany ponad 60 razy, w tym (nie licząc zmian wynikających z wyroków zakresowych Trybunału Konstytucyjnego) aż 25 razy w ostatnim dziesięcioleciu. Trzeba przy tym zauważyć, że gruntowne zmiany uregulowań kodeksowych, poza nielicznymi wyjątkami (należą do nich: wyłączenie spod regulacji kodeksowej postępowania podatkowego ${ }^{2}$ oraz nowelizacje z grudnia 2010 r. $^{3}$ i kwietnia 2017 r. ${ }^{4}$ ), były konsekwencją zmian prawno-ustrojowych o charakterze systemowym, takich jak: przywrócenie sądowoadministracyjnej kontroli rozstrzygnięć zapadających

1 Ustawa z dnia 14 czerwca 1960 - Kodeks postępowania administracyjnego (tekst jedn.: Dz. U z 2018 r., poz. 2096; dalej: k.p.a.).

2 Zob. art. 307 ustawy z dnia 29 sierpnia 1997 r. - Ordynacja podatkowa (Dz. U. Nr 137, poz. 926).

3 Ustawa z dnia 3 grudnia 2010 r. o zmianie ustawy - Kodeks postępowania administracyjnego oraz ustawy - Prawo o postępowaniu przed sądami administracyjnymi (Dz. U. z 2011 r. Nr 6, poz. 18).

4 Ustawa z dnia 7 kwietnia 2017 r. o zmianie ustawy - Kodeks postępowania administracyjnego oraz niektórych innych ustaw (Dz. U. z 2017 r., poz. 935). 
w postępowaniu administracyjnym ${ }^{5}$, reaktywowanie samorządu terytorialnego na szczeblu gminnym, i co za tym idzie - administracji samorządowej ${ }^{6}$, a następnie wprowadzenie dwóch kolejnych szczebli samorządu terytorialnego ${ }^{7}$.

Mówiąc o trwałości k.p.a. (z uwzględnieniem sygnalizowanych zmian, o których szerzej w dalszej części opracowania), należy uwzględnić jeszcze i to, że przyjęta w nim i obowiązująca do dzisiaj „filozofia” zasad i trybu stosowania norm administracyjnego prawa materialnego została wprowadzona do polskiego porządku prawnego dalece wcześniej, a mianowicie już w dwudziestoleciu międzywojennym. Wówczas to bowiem zostało wydane rozporządzenie Prezydenta Rzeczypospolitej Polskiej o postępowaniu administracyjnem ${ }^{8}$, którego obowiązujący kodeks jest bezpośrednim następcą. Mając i to na względzie, można by postawić wstępną hipotezę, w myśl której prawne regulacje k.p.a. w swym rdzeniu - zasadniczej warstwie - wytrzymały i nadal wytrzymują próbę czasu. Należałoby jednak przy tym nadmienić, że wyrażone powyżej stanowisko nie jest powszechnie aprobowane. Diagnoza co do aktualnej kondycji k.p.a. jest bowiem co najmniej niejednolita. Wyrazem tego jest tocząca się obecnie dyskusja nad dalszymi losami postępowania administracyjnego w jego dotychczasowej postaci oraz samego k.p.a. ${ }^{9}$

Jednym z istotnych aspektów, który należałoby wziąć pod uwagę w tej dyskusji jest ewoluujący w różnych okresach, okolicznościach i kierunkach przedmiot kodeksowej regulacji. Próba wyjaśnienia motywów oraz dokonania oceny zmieniającej się w ciągu 60 lat zawartości k.p.a. może być pomocna przy rozstrzyganiu o przyszłości obowiązującej regulacji kodeksowej.

\footnotetext{
5 Ustawa z dnia 31 stycznia 1980 r. o Naczelnym Sądzie Administracyjnym oraz o zmianie ustawy Kodeks postępowania administracyjnego (Dz. U. Nr 4, poz. 8 ze zm.).

6 Ustawa z dnia 24 maja 1990 r. o zmianie ustawy - Kodeks postępowania administracyjnego (Dz. U. Nr 34, poz. 201).

7 Ustawa z dnia 29 grudnia 1998 r. o zmianie niektórych ustaw w związku z wdrożeniem reformy ustrojowej państwa (Dz. U. Nr 162, poz. 1126 ze zm.).

8 Rozporządzenie Prezydenta Rzeczypospolitej Polskiej z dnia 22 marca 1928 r. o postępowaniu administracyjnem (Dz. U. Nr 36, poz. 341).

9 Zob. na ten temat m.in.: Z. Kmieciak, Dylematy reformy prawa o postępowaniu administracyjnym, PiP 2016, z. 1, s. 3-17; idem, Oblicza nowelizacji kodeksu postępowania administracyjnego (w odpowiedzi prof. Janowi Zimmermannowi, PiP 2018, z. 2, s. 97-110; idem, Postępowanie administracyjne na rozdrożu?, PiP 2019, z. 10, s. 5-22; J. Zimmermann, Kilka refleksji o nowelizacji kodeksu postępowania administracyjnego, PiP 2017, z. 8, s. 3-24; M. Bogusz, Kodyfikacja postępowania administracyjnego a pojęcie postępowania administracyjnego [w:] Idea kodyfikacji w nauce prawa administracyjnego procesowego. Księga pamiątkowa Profesora Janusza Borkowskiego, red. W. Chróścielewski, Z. Kmieciak, Warszawa 2018, s. 55-63; M. Kamiński, Idea kodyfikacji w nauce prawa administracyjnego procesowego a procedury administracyjne regulacyjne. Uwagi teoretyczne i prawnoporównawcze [w:] Idea kodyfikacji w nauce prawa administracyjnego procesowego. Księga..., s. 121-137; D.R. Kijowski, Tendencje dekodyfikacji ogólnego postępowania administracyjnego w XXI w. [w:] Idea kodyfikacji..., s. 139-152; H. Knysiak-Sudyka, Kodeks postępowania administracyjnego - dokąd zmierza ustawodawca? [w:] Idea kodyfikacji..., s. 153-163.
} 


\section{Ewoluujący zakres regulacji k.p.a.}

Koncentrując się zatem w niniejszym opracowaniu na przedmiotowym zakresie regulacji k.p.a., trzeba wskazać, że ów zakres już od pierwszej wersji nie pokrywał się w pełni z nadaną mu nazwą, zwłaszcza gdy za mierniki adekwatności nazwy i jej desygnatu (desygnatów) zostaną obrane powszechnie uznane znaczenia pojęć: „postępowanie administracyjne" i „kodeks".

Postępowanie administracyjne, w szczególności w ścisłym jego znaczeniu, było nawet jeszcze w czasach przedkodeksowych ${ }^{10}$ definiowane względnie jednolicie. Mianowicie pod tym pojęciem w przeszłości, jak i obecnie rozumie się uregulowany prawem „ciąg czynności procesowych podejmowanych przez organy administracji publicznej oraz inne podmioty postępowania w celu rozstrzygnięcia sprawy indywidualnej w formie decyzji administracyjnej"11. Można by jeszcze między innymi za Wacławem Dawidowiczem dokonać, rozbudowania” tak określonego pojęcia postępowania administracyjnego, które nadal utrzyma swój ścisły sens (zresztą w zgodzie z normatywną tradycją), o przepisy normujące tryb załatwiania „sprawy weryfikacyjnej”, a więc takiej, której przedmiotem jest administracyjna weryfikacja ostatecznej decyzji administracyjnej ${ }^{12}$.

Z kolei pojęcie kodeksu, z punktu widzenia jego zawartości, obejmuje swym znaczeniem akty normatywne regulujące w sposób względnie całościowo ściśle określoną dziedzinę życia społecznego ${ }^{13}$.

Przyjmując zatem takie właśnie rozumienie wyrażeń „postępowanie administracyjne" i „kodeks", widać wyraźnie, że przepisy działu oznaczonego pierwotnie jako IV a obecnie VIII k.p.a. „Skargi i wnioski”, nie mieszczą się w wąskim ujęciu postępowania administracyjnego, ze względów przedmiotowych (nie normują trybu załatwiania sprawy administracyjnej ani weryfikacyjnej), a z uwagi na ich zakres podmiotowy obejmujący również organy, instytucje i organizacje niebędące organami administracji publicznej, wykraczają nawet poza szeroką koncepcję postępowania administracyjnego (postępowania prowadzonego przez organy administracji publicznej). Z tych to względów pojawiały się opinie, że postępowania w sprawie skarg i wniosków kwalifikują się do unormowania w osobnej ustawie ${ }^{14}$. Chociaż równocześnie przedstawiano

10 Por. E. Iserzon, Pojęcie procesu administracyjnego [w:] idem, W. Dawidowicz, J. Starościak, Podstawowe zagadnienia postępowania administracyjnego, Warszawa 1955, s. 18; J. Starościak, Zagadnienie budowy systemu postępowania administracyjnego [w:] idem, W. Dawidowicz, E. Iserzon, Podstawowe zagadnienia..., s. 30.

11 B. Adamiak, Zagadnienia ogólne procesowego prawa administracyjnego [w:] System Prawa Administracyjnego, t. 9, Prawo procesowe administracyjne, red. R. Hauser, Z. Niewiadomski, A. Wróbel, Warszawa 2010, s. 3. Zob. też m.in.: A. Matan, Postępowanie administracyjne sensu stricto [w:] System Prawa Administracyjnego Procesowego, t. 1, Zagadnienia ogólne, red. G. Łaszczyca, A. Matan, Warszawa 2017, s. 216-219.

12 Por. W. Dawidowicz, Zarys procesu administracyjnego, Warszawa 1989, s. 13-14.

13 Por. m.in.: A. Wasilewski, Kodyfikacja prawa administracyjnego. Idea i rzeczywistość, Warszawa 1988, s. 10; Encyklopedia prawa, red. U. Kalina-Prasznic, Warszawa 1999, s. 246.

14 R. Orzechowski [w:] idem, J. Borkowski, J. Jendrośka, A. Zieliński, Kodeks postępowania administracyjnego. Komentarz, Warszawa 1989, s. 35. 
argumentacje przemawiające za ścisłym powiązaniem tychże postępowań z ogólnym postępowaniem administracyjnym ${ }^{15}$. Nie podejmując się próby sformułowania kategorycznego stanowiska w tej kwestii, które wymagałoby przeprowadzenia analizy wykraczającej poza przedmiot i charakter niniejszej opracowania, wypada jednak zwrócić uwagę na widoczną w obowiązującym porządku prawnym już od kilku lat koncepcyjną niekonsekwencję. Otóż 6 września 2015 r. weszła w życie ustawa ${ }^{16}$ regulująca zasady składania i rozpatrywania petycji oraz sposób postępowania organów w sprawach dotyczących petycji, wyłączając równocześnie (chociaż nie całkowicie) tę kategorię środków komunikowania przez jednostki i ich organizacje swoich stanowisk organom władzy oraz organizacjom i instytucjom społecznym, spod reżimu przepisów k.p.a. Do tego bowiem czasu (a począwszy od 1 stycznia 1999 r.) petycje, co prawda w sposób niezwykle zdawkowy, były unormowane w art. 221 k.p.a. ${ }^{17}$

Powyższa decyzja ustawodawcy rodzi wątpliwości z perspektywy systemowej. Pierwsza wątpliwość dotyczy powodów, dla których, uzasadnione skądinąd rozwinięcie regulacji określających zasady składania i rozpatrywania petycji oraz sposoby postępowania w sprawach dotyczących petycji, stanowiące realizację postanowień art. 63 Konstytucji RP18, nie zostało ujęte w dziale VIII k.p.a. ${ }^{19}$ Wątpliwość druga, ściśle związana z pierwszą (aczkolwiek biegunowo odmienną), sprowadza się do pytania o to, dlaczego podjęta przez ustawodawcę decyzja o uregulowaniu tego niejurysdykcyjnego postępowania poza k.p.a. ograniczyła się wyłącznie do petycji, pozostawiając w kodeksowej strukturze zbliżone do siebie rodzajowo instytucje, jakimi są skargi i wnioski ${ }^{20}$. Wreszcie trzecia wątpliwość ponownie dotyczy zasadności wyłączenia instytucji petycji poza zakres przedmiotowy kodeksu. Jej powodem jest treść art. 15 ustawy o petycjach, zgodnie z którym: „W zakresie nieuregulowanym w ustawie do petycji stosuje się odpowiednio przepisy ustawy z dnia 14 czerwca 1960 r. - Kodeks postępowania administracyjnego (...)". Trywializując nieco obecny stan, można stwierdzić,

\footnotetext{
15 Zob. m.in. J. Borkowski [w:] idem, B. Adamiak, Kodeks postępowania administracyjnego. Komentarz, Warszawa 1997, s. 372-373.

16 Ustawa z dnia 11 lipca 2014 r. o petycjach (Dz. U. poz. 1195; dalej: ustawa o petycjach).

17 Zgodnie z art. 221 k.p.a. w brzmieniu ustalonym przez art. 2 pkt 34 ustawy z dnia 29 grudnia 1998 r. o zmianie niektórych ustaw w związku z wdrożeniem reformy ustrojowej państwa (Dz. U. Nr 162, poz. 1126): „§ 1. Zagwarantowane każdemu w Konstytucji Rzeczypospolitej Polskiej prawo składania petycji, skarg i wniosków do organów państwowych, organów jednostek samorządu terytorialnego, organów samorządowych jednostek organizacyjnych oraz do organizacji i instytucji społecznych realizowane jest na zasadach określonych przepisami niniejszego działu. § 2. Petycje, skargi i wnioski mogą być składane do organizacji i instytucji społecznych w związku z wykonywanymi przez nie zadaniami zleconymi z zakresu administracji publicznej. § 3. Petycje, skargi i wnioski można składać w interesie publicznym, własnym lub innej osoby za jej zgodą".

18 Por. uzasadnienie projektu ustawy o petycjach z dnia 18 grudnia 2013 r., http://orka.sejm.gov.pl/ Druki7ka.nsf/0/468173F83ED010BFC1257C7D0044FEB7/\%24File/2135.pdf [dostęp: 22.01.2020].

19 Zob. też C. Martysz, O potrzebie dalszej unifikacji postępowania administracyjnego [w:] Idea kodyfikacji w nauce prawa administracyjnego procesowego. Księga..., s. 221-223.

20 Zob. na ten temat: J. Lang, Kilka uwag na temat pojęć petycji, skargi i wniosku oraz ustawowej regulacji zasad i trybu ich rozpatrywania [w:] Skargi, wnioski i petycje - powszechne środki ochrony prawnej, red. M. Błachucki, G. Sibiga, Wrocław 2017, s. 28-29.
} 
że zasady składania i rozpatrywania petycji zostały wyodrębnione spod reżimu k.p.a. i równocześnie w tymże reżimie pozostawione.

Przełomowym wydarzeniem w historii obowiązywania k.p.a., ale również w kontekście całego ówczesnego systemu prawa i postępowania administracyjnego, a widocznym wyraźnie także z punktu widzenia znacznego poszerzenia przedmiotu regulacji, była nowelizacja ${ }^{21}$ z 1980 r. Zawarte w niej przepisy wzbogaciły dotychczasowy katalog procedur kolejno o: 1) uregulowania szczególne postępowań w sprawach zobowiązań podatkowych oraz ubezpieczeń społecznych; 2) zasady i tryb rozstrzygania sporów o właściwość między organami administracji państwowej a sądami; 3) unormowania dotyczące zakresu i sposobu zaskarżania decyzji do sądu administracyjnego oraz toku postępowania i prawnych konsekwencji zapadłych rozstrzygnięć; 4) wydawania zaświadczeń.

Objęcie spraw z zakresu zobowiązań podatkowych oraz ubezpieczeń społecznych regulacją przepisów k.p.a., z uwzględnieniem odrębności określonych w dodanym dziale II (w późniejszej numeracji - w dziale III22), w pełni wpisuje się w ideę kodyfikacji, której jednym z celów jest zespolenie regulacji normujących daną dziedzinę ${ }^{23}$, na którą w tym przypadku składają się zasady i tryby załatwiania przez organy administracji publicznej indywidualnych spraw podmiotów niezwiązanych organizacyjnie z tymi organami.

Zgoła inaczej wypadałoby podejść do oceny poszerzenia przedmiotu normowania przepisów k.p.a. o regulacje dotyczące rozstrzygania sporów o właściwość między organami administracji państwowej a sądami. Nie ulega wątpliwości, że przedmiotem postępowania określonego przez przepisy działu III' (w późniejszej numeracji - działu V), nie jest sprawa administracyjna. Co prawda w k.p.a. od samego początku były zawarte stosowne rozwiązania na wypadek powstania sporów o właściwość, które również bezpośrednio nie prowadziły do rozstrzygnięcia sprawy administracyjnej, jednakże dotyczyły one sporów pomiędzy organami administracji publicznej, a więc miały i do chwili obecnej mają zastosowanie w sytuacjach, "gdy nie jest kwestionowana administracyjna droga rozstrzygnięcia sprawy"24. Natomiast przepisy dodane miały na celu określenie sposobu i trybu, rozstrzygnięcia o tym czy w spornym przypadku właściwa będzie droga administracyjna czy sądowa. Zatem odnosiły się do sporów "zewnętrznych" powstałych między organami realizującymi odmienne funkcje państwowe ${ }^{25}$. Jak podkreśla się w doktrynie, Kolegium Kompetencyjnemu przy Sądzie

21 Ustawa z dnia 31 stycznia 1980 r. o Naczelnym Sądzie Administracyjnym oraz o zmianie ustawy Kodeks postępowania administracyjnego (Dz. U. Nr 4, poz. 8).

22 Nowa numeracja struktury i poszczególnych przepisów k.p.a. została wprowadzona w tekście jednolitym ogłoszonym obwieszczeniem Prezesa Rady Ministrów z dnia 17 marca 1980 r. w sprawie ogłoszenia jednolitego tekstu ustawy z dnia 14 czerwca 1960 r. - Kodeks postępowania administracyjnego (Dz. U. Nr 9, poz. 26).

23 Encyklopedia prawa...

24 A. Wróbel [w:] idem, M. Jaśkowska, Kodeks postępowania administracyjnego. Komentarz, Kraków 2005, s. 199.

25 J. Borkowski, Podstawowe zmiany w kodeksie postępowania administracyjnego [w:] Kodeks postępowania administracyjnego po nowelizacji, red. S. Zawadzki, Warszawa 1980, s. 128. 
Najwyższym, ustanowionemu w celu rozstrzygania powyższych sporów, „nadano pozycję organu sądowego, działającego w szczególnym składzie osobowym, ale z zachowaniem czynnika sędziowskiego"26.

Warto też przypomnieć, że art. 20 k.p.a. w brzmieniu sprzed omawianej nowelizacji stanowił: „Zasady i tryb rozstrzygania sporów o właściwość między organami administracji państwowej a sądami określi ustawa". Przepis ten można by potraktować w kategoriach stanowiska ustawodawcy z 1960 r., optującego za spójnością przedmiotową kodeksowej regulacji. Po niespełna dwudziestu latach „ustawą", o której mowa w cytowanym przepisie, okazał się sam kodeks. Dodanie do k.p.a. działu III' oraz dwóch następnych działów, o których poniżej, należałoby uznać za odejście od ścisłego traktowania tego aktu normatywnego zgodnie z jego nazwą jako zbioru przepisów normujących zasady i tryb postępowania administracyjnego i wykorzystanie formuły kodeksowej do konsolidacji procedur (i nie tylko procedur) dotyczących bądź związanych ze stosowaniem norm administracyjnego prawa materialnego, ale i w różnym stopniu związanych z działalnością podmiotów administrujących oraz z realizacją szeroko rozumianej administracji publicznej w ujęciu przedmiotowym.

Nowela k.p.a. z 1980 r. stanowiła ważny element głębokiej reformy w obszarze ówczesnego prawa publicznego, której najistotniejszym rezultatem było przywrócenie polskiemu porządkowi prawno-ustrojowemu działającego w okresie międzywojennym sądownictwa administracyjnego ${ }^{27}$. W koncepcji przyjętej przywołaną powyżej ustawą z dnia 31 stycznia 1980 r. i obowiązującej przez kolejne piętnaście lat, podstawowe normatywne zręby postępowania przed Naczelnym Sądem Administracyjnym zostały zamieszczone w dziale III² k.p.a. (w późniejszej numeracji - w dziale VI) zatytułowanym „Zaskarżanie decyzji do sądu administracyjnego", zaś w sprawach tam nieuregulowanych miały odpowiednie zastosowanie przepisy kodeksu postępowania cywilnego ${ }^{28}$. Motywów takiego zabiegu legislacyjnego (podobnie zresztą jak w przypadku inkorporowania do k.p.a. przepisów normujących rozstrzyganie sporów o właściwość między organami administracji państwowej a sądami) nie należy doszukiwać się w systemie normatywnym prawa i postępowania administracyjnego. Poza dyskusją pozostaje bowiem to, że postępowanie przed sądem administracyjnym ani wówczas, ani obecnie nie może być utożsamiane z jakąś choćby szczególną postacią postępowania administracyjnego albo też jego "ciągiem dalszym”29. Są to, co należy wyraźnie zaznaczyć, „dwa zupełnie różne jakościowo systemy"30 postępowania prawnego. Natomiast

26 J. Borkowski [w:] idem, B. Adamiak, Kodeks postępowania administracyjnego..., s. 813-814.

27 W okresie międzywojennym sądownictwo administracyjne funkcjonowało na podstawie ustawy z dnia 3 sierpnia 1922 r. o Najwyższym Trybunale Administracyjnym (Dz. U. Nr 68, poz. 400 ze zm.), a następnie rozporządzenia Prezydenta Rzeczypospolitej z dnia 27 października 1932 r. o Najwyższym Trybunale Administracyjnym (Dz. U. Nr 94, poz. 806 ze zm.).

28 Szerzej na temat tych rozwiązań zob. A. Zieliński, Postępowanie przed Naczelnym Sądem Administracyjnym [w:] Kodeks postępowania administracyjnego po nowelizacji..., s. 100-118.

29 Ujęcie postępowania sądowoadministracyjnego jako kontynuacji jurysdykcyjnego postępowania administracyjnego pojawia się w literaturze, ale ma ono stricte umowny charakter - zob. J. Zimmermann, Aksjomaty postępowania administracyjnego, Warszawa 2017, s. 249 i n.

30 W. Dawidowicz, Prawo administracyjne, Warszawa 1987, s. 37. 
za powód umieszczenia podstawowych przepisów regulujących postępowanie przed sądem administracyjnym w k.p.a. można by uznać co najwyżej ówczesną kognicję NSA, ograniczoną wyłącznie do decyzji administracyjnych (i to tylko w sprawach wyraźnie określonych w art. 196 k.p.a.). Powyższa i tak nie dość mocna argumentacja, jeśli się nawet nie zdezaktualizowała, to z pewnością doznała znacznego osłabienia na skutek objęcia sądowoadministracyjną kontrolą uchwał organów gminy, rozstrzygnięć organu nadzorczego dotyczących gminy oraz stanowisk organu, o których mowa w art. 89 ustawy o samorządzie gminnym ${ }^{31}$, zgodnie z art. 216a k.p.a., dodanym w 1990 r. $^{32}$ w związku z reaktywacją samorządu terytorialnego na szczeblu gminnym.

Ostatni z dołączonych przez nowelę z 1980 r. działów k.p.a. - dział III³ (w obecnej numeracji oznaczony jako dział VII) zatytułowany „Wydawanie zaświadczeń" nie powinien budzić aż tak kategorycznych zastrzeżeń co do stopnia zbieżności przedmiotu regulacji uzasadniającego uznanie zawartych w nim przepisów za merytorycznie odpowiadające kodeksowej materii. W literaturze przyjęło się nawet określanie postępowania w sprawie wydawania zaświadczeń (zresztą tak jak i postępowań w sprawach skarg i wniosków, chociaż w tym przypadku podobieństwa przedmiotowe są w mojej ocenie znacznie mniejsze) mianem administracyjnego postępowania uproszczonego ${ }^{33}$. Co prawda przedmiotem tego postępowania nie jest sprawa administracyjna rozstrzygana w drodze decyzji administracyjnej, ale zarówno kontekst podmiotowy (nawiązanie stosunku administracyjnoprawnego pomiędzy organem administrującym i podmiotem spoza systemu administracji publicznej) oraz podłoże materialnoprawne, stanowiące przyczynę uruchomienia postępowania o wydanie zaświadczenia ${ }^{34}$, świadczą o zasadności konsolidacji tychże uregulowań z przepisami normującymi postępowania jurysdykcyjne w sprawach, o których mowa w art. 1 pkt 1 k.p.a.

Na odrębną uwagę w świetle dokonywanej „inwentaryzacji” zawartości k.p.a. zasługuje grupa przepisów częściowo zamieszczonych już w jego pierwotnej wersji, a następnie poszerzona i zmodyfikowana przepisami noweli z 1980 r. oraz późniejszymi zmianami. Przy zastosowaniu obecnej numeracji, chodzi tu mianowicie o przepisy art. 154, 155, 161 i 162 k.p.a., określające - posiłkując się terminologią użytą przez W. Dawidowicza - materialne reguły uchylania, zmiany i stwierdzania wygaśnięcia

31 Ustawa z dnia 8 marca 1990 r. o samorządzie gminnym (tekst jedn.: Dz. U. z 2019 r., poz. 506 ze zm.), pierwotnie - ustawa z dnia 8 marca 1990 r. o samorządzie terytorialnym (Dz. U. Nr 16, poz. 95).

32 Zob. przyp. 6.

33 Zob. m.in.: J. Borkowski, Uproszczone postępowania o charakterze administracyjnym [w:] idem, B. Adamiak, Polskie postępowanie administracyjne i sq̨dowoadministracyjne, Warszawa 1993, s. 357 i n. Pojęcie administracyjnego postępowania uproszczonego, zwłaszcza w świetle nowelizacji k.p.a. z 2017 r. (o czym szerzej w dalszej części opracowania), nabiera obecnie odmiennego znaczenia. Zob. na ten temat: M. Jaśkowska, Kodyfikacja administracyjnych postępowań uproszczonych [w:] Idea kodyfikacji..., s. 95-108.

34 Zgodnie z art. 217 § 2 k.p.a., zaświadczenie wydaje się, jeżeli: 1) urzędowego potwierdzenia określonych faktów lub stanu prawnego wymaga przepis prawa; 2) osoba ubiega się o zaświadczenie ze względu na swój interes prawny w urzędowym potwierdzeniu określonych faktów lub stanu prawnego. 
decyzji ostatecznej35. W rzeczy samej treść tych przepisów trudno uznać za źródło rekonstrukcji norm procesowych. Ujęcie tego rodzaju przepisów w ustawie z nazwy oraz w dominującej części regulacji procesowej, może budzić wątpliwości z punktu widzenia przyjętych zasad systematyki prawa, zaś usprawiedliwienia dla takiej decyzji prawodawcy należy upatrywać głównie w fakcie nieskodyfikowania pozostałych obszarów szeroko rozumianego prawa administracyjnego ${ }^{36}$.

U progu lat 90. porządek kodeksowy ukształtowany nowelizacją z 1980 r. wszedł w fazę przeobrażeń, które w dużej mierze były wypadkową zapoczątkowanych w tym czasie przemian ustrojowych. Przepisy k.p.a. wymagały dostosowania do nowych uwarunkowań, wynikających z powrotu do systemu administracji publicznej organów samorządu terytorialnego, zaś na nowo formułowana przestrzeń swobód obywatelskich znalazła swoje odzwierciedlenie między innymi w znacznym poszerzeniu - przedmiotowego zakresu kontroli sprawowanej przez Naczelny Sąd Administracyjny ${ }^{37}$. Z perspektywy rzeczowego zakresu regulacji k.p.a., kluczowe zmiany nastąpiły w latach 1995 i 1997. W 1995 r. została uchwalona i weszła w życie ustawa o Naczelnym Sądzie Administracyjnym ${ }^{38}$, która oprócz przepisów ustrojowych normowała tryb postępowania przed NSA, wyłączając tym samym materię ujętą w dziale VI spod regulacji kodeksowej. Ustawa z 1995 r., nawiązując do rozwiązań przedwojennych, a więc uregulowania postępowania administracyjnego i sądowoadministracyjnego w odrębnych aktach normatywnych, wychodziła tym samym naprzeciw postulatom zgłaszanym już w latach $80 .{ }^{39}$ Przeniesienie prawnej regulacji postępowania przed NSA poza k.p.a. należy uznać za korzystne zarówno z punktu widzenia tożsamości nazwy i treści kodeksowych regulacji, jak również przedmiotowej jedności kodyfikowanej materii. Aczkolwiek warto w tym miejscu zaznaczyć, że przywołana ustawa nie odcięła się zupełnie od k.p.a. $Z$ uwagi na niewyczerpującą regulację (podobnie zresztą jak w okresie 1980-1995) w sprawach nieunormowanych ustawą o Naczelnym Sądzie Administracyjnym z 1995 r. miały zastosowanie, podobnie jak dotychczas, przepisy kodeksu postępowania cywilnego, ale ponadto należało także odpowiednio stosować art. 7-9, art. 11 - art. $14 \S 1$, art. 29-32, art. 39-49, art. 57-60, art. 73, art. 74 § 1, art. 75-85, art. 97, art. 98, art. $101 \S 1$ i 2, art. 103 i art. 146 k.p.a. Od odpowiedniego stosowania przepisów k.p.a. odstąpiono dopiero w 2004 r., w którym to weszła w życie obecnie obowiązująca ustawa o postępowaniu przed sądami administracyjnymi ${ }^{40}$, przy czym i ona - chociaż w zupełnie innym kontekście - odwołuje się do kodeksowej regulacji postępowania administracyjnego ${ }^{41}$.

35 Por. W. Dawidowicz, Zarys procesu..., s. 202.

36 Uwagi krytyczne wobec takiego rozwiązania - zob. m.in. W. Dawidowicz, Postępowanie administracyjne. Zarys wykładu, Warszawa 1983, s. 238-241.

37 Zob. ustawa z dnia 24 maja 1990 r. o zmianie ustawy - Kodeks postępowania administracyjnego (Dz. U. Nr 34, poz. 201).

38 Ustawa z dnia 11 maja 1995 r. o Naczelnym Sądzie Administracyjnym (Dz. U. Nr 74, poz. 368 ze zm.).

39 Zob. m.in. W. Dawidowicz, Prawo..., s. 40.

40 Ustawa z dnia 30 sierpnia 2002 r. o postępowaniu przed sądami administracyjnymi (tekst jedn.: Dz. U. z 2019 r., poz. 2325 ze zm.).

41 Zob. m.in.: art. 145 § 1 pkt 2 i 3 przywołanej wyżej ustawy. 
Również w 1997 r. doszło do uszczuplenia przedmiotu kodeksowej regulacji, przy czym tym razem ze szkodą dla celów i funkcji, jakie przypisuje się aktom kodyfikującym poszczególne działy prawa. Otóż dnia 29 sierpnia 1997 r. została uchwalona ordynacja podatkowa ${ }^{42}$. Co warte podkreślenia - akt ten został ustanowiony z myślą o konsolidacji czy wręcz kodyfikacji newralgicznego dla gospodarki i finansów państwa działu prawa, jakim jest prawo podatkowe, a ściślej - jego część ogólna. W rezultacie jedną z konsekwencji tejże konsolidacji była częściowa dekodyfikacja postępowania administracyjnego polegająca na wyłączeniu go spod reżimu k.p.a. postępowania w sprawach zobowiązań podatkowych. Przeniesienie postępowania podatkowego z k.p.a. do ordynacji podatkowej można rozpatrywać i oceniać przez pryzmat dwóch przeciwstawnych koncepcji: unifikacji i odrębności postępowania podatkowego. Koncepcje te ścierają się w płaszczyźnie normatywnej, co ilustrują przywołane powyżej regulacje, ale i także rozwiązania z dalszej przeszłości, w tym przepisy przedwojennej ordynacji podatkowej ${ }^{33}$ normującej m.in. „Postępowanie przy wymiarze podatków”. Problem ten jest również przedmiotem dyskusji współczesnej doktryny prawa i postępowania administracyjnego ${ }^{44}$.

Dekonsolidacja czy też nawet fragmentaryczna dekodyfikacja k.p.a. nie sprowadza się li tylko do wyodrębnienia spod kodeksowej regulacji przepisów o postępowaniu podatkowym. W ciągu obowiązywania k.p.a., a zwłaszcza w ostatnim trzydziestoleciu narasta tendencja do ustanawiania przepisów proceduralnych, które na potrzeby poszczególnych kategorii spraw administracyjnych dokonują z reguły drobnych, ale i również w niektórych przypadkach znaczących modyfikacji wobec kodeksowego standardu jurysdykcyjnego postępowania administracyjnego. Reprezentatywnymi w tym względzie przykładami są szczególne rozwiązania procesowe zawarte w tzw. specustawach inwestycyjno-budowlanych ${ }^{45}$ oraz w ustawach normujących tzw. postępowania hybrydowe, w których w miejsce administracyjnego postępowania odwoławczego wprowadza się możliwość weryfikacji rozstrzygnięcia organu administracji publicznej przez sąd powszechny ${ }^{46}$. Rozwiązania te (jeśli nie wszystkie, to przynajmniej część z nich) znajdują merytoryczne - racjonalne uzasadnienie w specyfice danego rodzaju sprawy administracyjnej i jej materialnoprawnych uwarunkowaniach. Należałoby jednak postulować, by ustawodawca przed podjęciem decyzji o kolejnym odstępstwie od przyjętego w k.p.a. trybu załatwiania spraw administracyjnych, dokonywał

42 Ustawa z dnia 29 sierpnia 1997 r. - Ordynacja podatkowa (Dz. U. Nr 137, poz. 926; tekst jedn.: Dz. U. z 2019 r. poz. 900 ze zm.; dalej: ordynacja podatkowa).

43 Ustawa z dnia 15 marca 1934 r. - Ordynacja Podatkowa (Dz. U. Nr 39, poz. 346 ze zm.).

44 Stanowiska w tym względzie przedstawiają m.in.: J. Zimmermann, Ordynacja podatkowa. Komentarz. Postępowanie podatkowe, Toruń 1998, s. 5 i n. oraz Z. Kmieciak, Zarys teorii postępowania administracyjnego, Warszawa 2014, s. 70 i n.

45 P. Ostojski, Cele szczególnych regulacji prawnoprocesowych w tak zwanych specustawach inwestycyjnych [w:] Specustawy inwestycyjno-budowlane, red. T. Bąkowski, Gdańsk 2020, s. 255 i n.; K. Kaszubowski, Odrębności procesowe w specustawach inwestycyjnych w zakresie postępowania odwoławczego [w:] Specustawy..., s. 273 i.

46 Zob. Z. Czarnik, W sprawie charakteru prawnego tzw. postępowań hybrydowych, ZNSA 2015, z. 2, s. $22-32$. 
każdorazowego „bilansu zysków i strat”, w świadomości tego, że kolejne odstępstwo przyczynia się do erozji „kodeksowego charakteru” jurysdykcyjnego postępowania administracyjnego, a co za tym idzie - przyczynia się do wzrostu komplikacji i zawiłości porządku prawnego.

W 2004 r. wraz z reformą sądownictwa administracyjnego doszło do jeszcze jednego uszczuplenia zakresu regulacji k.p.a. Tym razem na mocy art. 4 pkt 7 ustawy wprowadzającej prawo o ustroju sądów administracyjnych oraz o postępowaniu przed sądami administracyjnymi ${ }^{47}$, wyeliminowano z kodeksowej regulacji zamieszczone w dziale $V$ przepisy dotyczące rozstrzygania sporów o właściwość między organami administracji publicznej a sądami powszechnymi, które - jak już wyżej wspomniano - budziły wątpliwości co do umieszczenia ich w k.p.a. Zabieg ten był konsekwencją zmian, jakie niosły za sobą wprowadzane ustawy, które sprawiły, że przepisy działu V stały się bezprzedmiotowe ${ }^{48}$.

Ostatnia z obszernych nowelizacji k.p.a., dokonująca istotnych zmian w przedmiocie kodeksowej regulacji, została wprowadzona przepisami ustawy ${ }^{49}$ z 2017 r. zmieniającej k.p.a. Ustawa ta stanowiła część - przygotowanego przez struktury ówczesnego Ministerstwa Rozwoju - pakietu: „100 zmian dla firm - Pakiet ułatwień dla przedsiębiorców" ${ }^{\prime 50}$. Przepisy te w zakresie nowelizacji k.p.a., w szczególności: 1) poszerzyły katalog zasad ogólnych postępowania ${ }^{51}$; 2 ) objęły swoim unormowaniem prawną konstrukcję milczącego załatwiania sprawy administracyjnej; 3) określiły warunki i tryb przeprowadzania mediacji w toku postępowania; 4) wprowadziły postępowanie uproszczone; 5) rozbudowały katalog kodeksowej regulacji o przepisy dotyczące nakładania lub wymierzania administracyjnych kar pieniężnych lub udzielanie ulg w ich wykonaniu oraz o: 6) uregulowania europejskiej współpracy administracyjnej. Już choćby z tego zestawienia dokonanych zmian, niebędącego katalogiem zamkniętym, widać skalę kodeksowych przeobrażeń, które z natury rzeczy stały się i nadal są przedmiotem ożywionej dyskusji ${ }^{52}$.

\footnotetext{
47 Ustawa z dnia 30 sierpnia 2002 r. - Przepisy wprowadzające ustawę - Prawo o ustroju sądów administracyjnych i ustawę - Prawo o postępowaniu przed sądami administracyjnymi (Dz. U. Nr 153, poz. 1271).

48 Zob. na ten temat: P. Przybysz, Kodeks postępowania administracyjnego. Komentarz, Warszawa 2017, s. 627. Należy przy tym zaznaczyć, że brak skonsolidowanych przepisów zastępujących uregulowania działu V k.p.a. został krytycznie oceniony przez część przedstawicieli doktryny prawa; zob. M. Jaśkowska [w:] eadem, A. Wróbel, Kodeks postępowania administracyjnego. Komentarz, Kraków 2005, s. 1050-1053; zob. też przywołaną tam literaturę.

49 Ustawa z dnia 7 kwietnia 2017 r. o zmianie ustawy - Kodeks postępowania administracyjnego (Dz. U. z 2017 r., poz. 935).

50 Zob. ocenę skutków regulacji, zawartą w projekcie ustawy nowelizującej k.p.a., druk nr 1183, http://orka.sejm.gov.pl/Druki8ka.nsf/0/F3388D1AB00B1313C125809D004C3C8E/\%24File/1183. pdf [dostęp: 31.01.2020].

51 Na ten temat zob. m.in. H. Knysiak-Sudyka, Ocena regulacji art. 7a, $7 b$ i 8 Kodeksu postępowania administracyjnego - czy ustawodawca stworzył nowe zasady postępowania administracyjnego? ,"Casus" 2019, nr 93, s. 6-11; A. Wiktorowska, Ozasadach ogólnych Kodeksu postępowania administracyjnego raz jeszcze [w:] Idea..., 351-366.

52 Zob. m.in. publikacje przywołane w przyp. 10.
} 
Uwzględniając temat niniejszego opracowania, należałoby się odnieść przede wszystkim do dwóch ostatnich z wymienionych wyżej nowości ujętych w dodanych w tym celu działach: w dziale IVa zatytułowanym „Administracyjne kary pieniężne" oraz w dziale VIIla - „Europejska współpraca administracyjna”.

Przepisy działu IVa można by nazwać częścią ogólną czy też wspólną, dla obecnie coraz częściej wykorzystywanych sankcji wobec zachowań niezgodnych z normą administracyjnego prawa materialnego przybierających postać kary pieniężnej nakładanej lub wymierzanej przez organ administracji publicznej w drodze decyzji administracyjnej. Swoisty renesans administracyjnych kar pieniężnych, trwający przynajmniej od końca XX wieku oraz pojawiające się w tym zakresie problemy, zwłaszcza w praktyce stosowania prawa, w pełni uzasadniają wprowadzenie do obowiązującego porządku prawnego „przepisów wspólnych” dla regulacji przewidujących sankcjonowanie naruszenia prawa administracyjnymi karami pieniężnymi, czy nawet szerzej - jak podnosi się w literaturze - również dla innych prawem przewidzianych środków reakcji na stan niezgodny z treścią normy prawa administracyjnego ${ }^{53}$. Celem tych przepisów, co poniekąd zostało zrealizowane wobec instytucji administracyjnych kar pieniężnych, było zagwarantowanie niezbędnej ochrony prawnej podmiotowi, którego zachowanie doprowadziło do zastosowania sankcji administracyjnej (w tym przypadku administracyjnej kary pieniężnej). Wypada choćby wspomnieć, że idące w tym kierunku rozwiązania stanowią przynajmniej częściowe wypełnienie rekomendacji nr R (91) 1 Komitetu Ministrów Rady Europy z dnia 13 lutego 1991 r. w sprawie sankcji administracyjnych ${ }^{54}$.

Ta generalna aprobata wobec wprowadzenia do obowiązującego porządku prawnego omawianych przepisów nie może objąć decyzji o ulokowaniu ich w k.p.a. Kluczowym zastrzeżeniem w tym względzie jest w dominującej mierze materialnoprawny charakter norm rekonstruowanych z przepisów działu IVa k.p.a. ${ }^{55}$ Ponadto decyzja ta świadczy o braku po stronie ustawodawcy spójnej legislacyjnej wizji, przynajmniej w obszarze regulacji administracyjnoprawnych. Można by bowiem (chociaż akurat sam nie jestem zwolennikiem takiego rozwiązania) zastosować czysto konwencjonalne podejście do k.p.a., a co za tym idzie - odejść od przypisywania nadmiernej wagi tożsamości nazwy aktu prawnego i jego zawartości, traktując powyższy kodeks jako miejsce dla szczególnie doniosłych prawnie regulacji administracyjnoprawnych, również i tych niemających charakteru procesowego. Jednakże wówczas należałoby oczekiwać konsekwencji, której brakuje współczesnemu ustawodawcy, co wyraźnie widać na przykładzie wprowadzenia do k.p.a. działu o administracyjnych karach pieniężnych,

\footnotetext{
53 Por. K. Ziemski, Próba oceny trafności objęcia Kodeksem postępowania administracyjnego możliwości stosowania sankcji karnych przez administrację [w:] Idea..., 400-401.

54 Ibidem, passim.

55 Ibidem, s. 402; E. Bojanowski, Kara administracyjna. Kilka refleksji [w:] Fenomen prawa administracyjnego. Księga Jubileuszowa Profesora Jana Zimmermanna, red. W. Jakimowicz, M. Krawczyk, I. Niżnik-Dobosz, Warszawa 2019, s. 70; T. Bąkowski, Zasady nakładania kary administracyjnej i udzielania ulg w jej wykonaniu według projektu nowelizacji Kodeksu postępowania administracyjnego [w:] Społeczna gospodarka rynkowa, red. A. Powałowski, GSP 2017, t. 37, s. 381-382.
} 
przy równoczesnym pozostawieniu poza nim wspomnianych powyżej przepisów normujących zasady składania i rozpatrywania petycji.

Z kolei przepisom określającym zasady i tryb europejskiej współpracy administracyjnej, zawartym w dziale VIIla (zwłaszcza w ich zasadniczej części) nie można odmówić proceduralnego charakteru. Jednakże w tym przypadku należy zauważyć, że ich przedmiotowy zasięg dalece wykracza poza jurysdykcję administracyjną ${ }^{56}$. Przepisy te mogą bowiem, a nawet - z uwagi na ich kategoryczne brzmienie - powinny mieć zastosowanie również $\mathrm{w}$ administracyjnych postępowaniach kontrolnych, w procedurach sporządzania przez podmioty administrujące planów, strategii, programów, podejmowania rozstrzygnięć o charakterze wewnętrznym, czy też - czego nie można a priori wykluczyć - w procedurach prawotwórczych.

\section{Podsumowanie}

Przeprowadzony, w stopniu szczegółowości i wnikliwości adekwatnym do charakteru i ram edytorskich artykułu, ,"przegląd” zakresu regulacji k.p.a., ewoluującego w ciągu 60 lat, licząc od daty jego uchwalenia, wymaga stosownego podsumowania, w którym pozwolę sobie raz jeszcze odwołać się do myśli W. Dawidowicza. W podręczniku do prawa administracyjnego z 1987 r. Autor ten, będąc przeciwnym zamieszczaniu w k.p.a. przepisów dotyczących: rozstrzygania sporów o właściwość między organami administracji państwowej i sądami powszechnymi, zaskarżania decyzji do NSA, wydawania zaświadczeń oraz skarg i wniosków, pisze, że: „Taki zakres treści kodeksu jest niewątpliwie wytworem określonych warunków historycznych, nie oznacza to jednak, że ten „dar losu" należy przyjmować bezkrytycznie"57. Dzisiejsza perspektywa, między innymi dlatego, że szersza o ponad 30 lat od publikacji cytowanego fragmentu, sprawia, iż w dużej mierze nadal aktualne zastrzeżenia i wątpliwości dotyczące zawartości k.p.a. zdają się doznawać przynajmniej częściowego "usankcjonowania” za sprawą upływu czasu, jak i zarówno dawniejszą i współczesną „praktyką legislacyjną”. To zaś skłania do złagodzenia oceny zawartości kodeksowej regulacji, ujętej w sformułowanych poniżej wnioskach:

1. Nie bagatelizując konsekwencji wyodrębnienia spod regulacji k.p.a. postępowania podatkowego, jak również tendencji do obejmowania przepisów regulacyjnych trybem postępowania hybrydowego oraz wprowadzania szczególnych rozwiązań w procesie stosowania przepisów tzw. specustaw, wypada uznać, że na tle przyspieszonego postępu dekonsolidacji i fragmentaryzacji innych uregulowań,

\footnotetext{
56 Por. A. Cebera, J.G. Firlus, Jakość techniczno-legislacyjna regulacji kodeksowej na przykładzie przepisów normujq̨cych nakładanie lub wymierzanie administracyjnych kar pieniężnych oraz tryb europejskiej współpracy administracyjnej [w:] Fenomen prawa administracyjnego..., s. 79-81.

57 W. Dawidowicz, Prawo..., s. 37.
} 
w szczególności w obszarze prawa publicznego ${ }^{58}$, 60-letni kodeks nadal jawi się jako akt normatywny w znacznym stopniu kompleksowy, kompletny i trwały.

2. Głównej przyczyny zamieszczania w k.p.a. (dodatkowo) przepisów „nieprocesowych” należy upatrywać w braku skodyfikowanej tzw. części ogólnej administracyjnego prawa materialnego ${ }^{59}$. Fiasko dotychczasowych prób wprowadzenia do polskiego porządku prawnego ustawy - Przepisy ogólne prawa administracyjnego ${ }^{60}$, może służyć za usprawiedliwienie pozostawienia dotychczasowych i lokowania nowych wspólnych administracyjnemu prawu materialnemu uregulowań do czasu wypracowania i przeforsowania ustawy regulującej podstawowe zasady, instytucje i prawne konstrukcje tej gałęzi prawa. Należałoby przy tym zastrzec, że dopuszczalne ustępstwa dotyczące pozaprocesowej zawartości k.p.a. na rzecz „utylitaryzmu legislacyjnego" powinny mieścić się w racjonalnych granicach, poza którymi należałoby pozostawić rozwiązania budzące uzasadnione wątpliwości. Do takich to właśnie należałoby zaliczyć np. dodany w 2018 r. przepis art. 14a w brzmieniu:„Organy administracji publicznej umożliwiają stronom ocenę działania urzędów kierowanych przez te organy, w tym pracowników tych urzędów", który dodatkowo, z uwagi na miejsce ulokowania, posiada status zasady ogólnej postępowania administracyjnego.

3. Ewoluujący treściowo przez ostatnie 60 lat k.p.a. jawi się więc, nie tylko jako względnie kompleksowy zbiór sprawdzonych i udoskonalanych (dostosowywanych do ustrojowo-społeczno-gospodarczych uwarunkowań) przepisów normujących tryb załatwiania spraw administracyjnych i weryfikacyjnych, ale również jako depozytariusz systemowo doniosłych regulacji administracyjnoprawnych.

\section{$* * *$}

Wydaje się, że końcową notę obecnej kondycji k.p.a. najlepiej wyrażą słowa Janusza Borkowskiego zapisane w 9. tomie Systemu Prawa Administracyjnego: „Pomimo licznych zmian prawnych, konstrukcja KPA nie została nadwątlona i chyba stwarza nadal możliwości wprowadzania do niej elementów modernizacyjnych z zachowaniem ogólnego kształtu kodyfikacji zgodnego z tradycją ustawowo regulowanej procedury administracyjnej, utrwalonej w Polsce od dziesiątków lat"61.

\footnotetext{
58 Szerzej na ten temat zob. T. Bąkowski, Niedoskonałości legislacji administracyjnej (przykłady, konsekwencje, źródła i poszukiwanie sposobu sanacji) [w:] J. Jagielski, M. Wierzbowski, Prawo administracyjne dziś i jutro, Warszawa 2018, s. 576-577.

59 Kodyfikacja całości bądź chociażby znacznej części administracyjnego prawa materialnego, ze względu na charakter i niespotykanie szeroki zakres przedmiotowy tej gałęzi prawa, wydaje się przedsięwzięciem nawet nie tyle niemożliwym, ile niecelowym. Zob. m.in. T. Bąkowski, Kodyfikacja materialnego prawa administracyjnego [w:] Leksykon prawa administracyjnego materialnego. 100 podstawowych pojęć, red. idem, K. Żukowski, Warszawa 2016, s. 86-90.

60 Zob. na ten temat m.in. T. Bąkowski, W kierunku kodyfikacji administracyjnego prawa materialnego [w:] Studia ustrojoznawcze, red. A. Szmyt, GSP 2014, t. 31, s. 527-539.

61 J. Borkowski, Ewolucja regulacji polskiego prawa procesowego administracyjnego na tle europejskim [w:] System Prawa Administracyjnego, t. 9, Prawo procesowe administracyjne, red. R. Hauser, Z. Niewiadomski, A. Wróbel, Warszawa 2010, s. 69.
} 


\section{Literatura}

Adamiak B., Zagadnienia ogólne procesowego prawa administracyjnego [w:] System Prawa Administracyjnego, t. 9, Prawo procesowe administracyjne, red. R. Hauser, Z. Niewiadomski, A. Wróbel, Warszawa 2010.

Bąkowski T., Kodyfikacja materialnego prawa administracyjnego [w:] Leksykon prawa administracyjnego materialnego. 100 podstawowych pojęć, red. T. Bąkowski, K. Żukowski, Warszawa 2016.

Bąkowski T., Niedoskonałości legislacji administracyjnej (przykłady, konsekwencje, źródła i poszukiwanie sposobu sanacji) [w:] J. Jagielski, M. Wierzbowski, Prawo administracyjne dziś i jutro, Warszawa 2018.

Bąkowski T., W kierunku kodyfikacji administracyjnego prawa materialnego [w:] Studia ustrojoznawcze, red. A. Szmyt, „Gdańskie Studia Prawnicze" 2014, t. 31.

Bąkowski T., Zasady nakładania kary administracyjnej i udzielania ulg w jej wykonaniu według projektu nowelizacji Kodeksu postępowania administracyjnego [w:] Społeczna gospodarka rynkowa, red. A. Powałowski, „Gdańskie Studia Prawnicze” 2017, t. 37.

Bogusz M., Kodyfikacja postępowania administracyjnego a pojęcie postępowania administracyjnego [w:] Idea kodyfikacji w nauce prawa administracyjnego procesowego. Księga pamiątkowa Profesora Janusza Borkowskiego, red. Z. Kmieciak, W. Chróścielewski, Warszawa 2018.

Bojanowski E., Kara administracyjna. Kilka refleksji [w:] Fenomen prawa administracyjnego. Księga Jubileuszowa Profesora Jana Zimmermanna, red. W. Jakimowicz, M. Krawczyk, I. Niżnik-Dobosz, Warszawa 2019.

Borkowski J., Ewolucja regulacji polskiego prawa procesowego administracyjnego na tle europejskim [w:] System Prawa Administracyjnego, t. 9, Prawo procesowe administracyjne, red. R. Hauser, Z. Niewiadomski, A. Wróbel, Warszawa 2010.

Borkowski J., Podstawowe zmiany w kodeksie postępowania administracyjnego [w:] Kodeks postępowania administracyjnego po nowelizacji, red. S. Zawadzki, Warszawa 1980.

Borkowski J., Uproszczone postępowania o charakterze administracyjnym [w:] idem, B. Adamiak, Polskie postępowanie administracyjne i sq̨dowoadministracyjne, Warszawa 1993.

Borkowski J. [w:] idem, B. Adamiak, Kodeks postępowania administracyjnego. Komentarz, Warszawa 1997.

Borkowski J., Jendrośka J., Orzechowski R., Zieliński A., Kodeks postępowania administracyjnego. Komentarz, Warszawa 1989.

Cebera A., Firlus J.G., Jakość techniczno-legislacyjna regulacji kodeksowej na przykładzie przepisów normujących nakładanie lub wymierzanie administracyjnych kar pieniężnych oraz tryb europejskiej współpracy administracyjnej [w:] Fenomen prawa administracyjnego. Księga Jubileuszowa Profesora Jana Zimmermanna, red. W. Jakimowicz, M. Krawczyk, I. Niżnik-Dobosz, Warszawa 2019.

Czarnik Z., W sprawie charakteru prawnego tzw. postępowań hybrydowych, "Zeszyty Naukowe Sądownictwa Administracyjnego" 2015, z. 2.

Dawidowicz W., Postępowanie administracyjne. Zarys wykładu, Warszawa 1983.

Dawidowicz W., Prawo administracyjne, Warszawa 1987.

Dawidowicz W., Zarys procesu administracyjnego, Warszawa 1989.

Encyklopedia prawa, red. U. Kalina-Prasznic,Warszawa 1999.

Iserzon E., Pojęcie procesu administracyjnego [w:] idem, J. Starościak, W. Dawidowicz, Podstawowe zagadnienia postępowania administracyjnego, Warszawa 1955. 
Jaśkowska M., Kodyfikacja administracyjnych postępowań uproszczonych [w:] Idea kodyfikacji w nauce prawa administracyjnego procesowego. Księga pamiątkowa Profesora Janusza Borkowskiego, red. Z. Kmieciak, W. Chróścielewski, Warszawa 2018.

Jaśkowska M., Wróbel A., Kodeks postępowania administracyjnego. Komentarz, Kraków 2005.

Kamiński M., Idea kodyfikacji w nauce prawa administracyjnego procesowego a procedury administracyjne regulacyjne. Uwagi teoretyczne i prawnoporównawcze [w:] Idea kodyfikacji w nauce prawa administracyjnego procesowego. Księga pamiątkowa Profesora Janusza Borkowskiego, red. Z. Kmieciak, W. Chróścielewski, Warszawa 2018.

Kaszubowski K., Odrębności procesowe w specustawach inwestycyjnych w zakresie postępowania odwoławczego [w:] Specustawy inwestycyjno-budowlane, red. T. Bąkowski, Gdańsk 2020.

Kijowski D.R., Tendencje dekodyfikacji ogólnego postępowania administracyjnego wXXI w. [w:] Idea kodyfikacji w nauce prawa administracyjnego procesowego. Księga pamiq̨tkowa Profesora Janusza Borkowskiego, red. Z. Kmieciak, W. Chróścielewski, Warszawa 2018.

Kmieciak Z., Dylematy reformy prawa o postępowaniu administracyjnym, „Państwo i Prawo” 2016, z. 1.

Kmieciak Z., Oblicza nowelizacji kodeksu postępowania administracyjnego (w odpowiedzi prof. Janowi Zimmermannowi), „Państwo i Prawo” 2018, z. 2.

Kmieciak Z., Postępowanie administracyjne na rozdrożu? ,„Państwo i Prawo” 2019, z. 10.

Kmieciak Z., Zarys teorii postępowania administracyjnego, Warszawa 2014.

Knysiak-Sudyka H., Kodeks postępowania administracyjnego - dokąd zmierza ustawodawca? [w:] Idea kodyfikacji w nauce prawa administracyjnego procesowego. Księga pamiq̨tkowa Profesora Janusza Borkowskiego, red. Z. Kmieciak, W. Chróścielewski, Warszawa 2018.

Knysiak-Sudyka H., Ocena regulacji art. 7a, 7 b i 8 Kodeksu postępowania administracyjnego - czy ustawodawca stworzył nowe zasady postępowania administracyjnego?, „Casus" 2019, nr 93.

Lang J., Kilka uwag na temat pojęć petycji, skargi i wniosku oraz ustawowej regulacji zasad i trybu ich rozpatrywania [w:] Skargi, wnioski i petycje - powszechne środki ochrony prawnej, red. M. Błachucki, G. Sibiga, Wrocław 2017.

Martysz C., O potrzebie dalszej unifikacji postępowania administracyjnego [w:] Idea kodyfikacji w nauce prawa administracyjnego procesowego. Księga pamiątkowa Profesora Janusza Borkowskiego, red. Z. Kmieciak, W. Chróścielewski, Warszawa 2018.

Matan A., Postępowanie administracyjne sensu stricto [w:] System Prawa Administracyjnego procesowego, t. 1, Zagadnienia ogólne, red. G. Łaszczyca, A. Matan, Warszawa 2017.

Ostojski P., Cele szczególnych regulacji prawnoprocesowych w tak zwanych specustawach inwestycyjnych [w:] Specustawy inwestycyjno-budowlane, red. T. Bąkowski, Gdańsk 2020.

Przybysz P., Kodeks postępowania administracyjnego. Komentarz, Warszawa 2017.

Starościak J., Zagadnienie budowy systemu postępowania administracyjnego [w:] idem, E. Iserzon, W. Dawidowicz, Podstawowe zagadnienia postępowania administracyjnego, Warszawa 1955.

Wasilewski A., Kodyfikacja prawa administracyjnego. Idea i rzeczywistość, Warszawa 1988.

Wiktorowska A., O zasadach ogólnych Kodeksu postępowania administracyjnego raz jeszcze [w:] Idea kodyfikacji w nauce prawa administracyjnego procesowego. Księga pamiq̨tkowa Profesora Janusza Borkowskiego, red. Z. Kmieciak, W. Chróścielewski, Warszawa 2018.

Wróbel A. [w:] idem, M. Jaśkowska, Kodeks postępowania administracyjnego. Komentarz, Kraków 2005.

Zieliński A., Postępowanie przed Naczelnym Sądem Administracyjnym [w:] Kodeks postępowania administracyjnego po nowelizacji, red. S. Zawadzki, Warszawa 1980. 
Ziemski K., Próba oceny trafności objęcia Kodeksem postępowania administracyjnego możliwości stosowania sankcji karnych przez administrację [w:] Idea kodyfikacji w nauce prawa administracyjnego procesowego. Księga pamiątkowa Profesora Janusza Borkowskiego, red. Z. Kmieciak, W. Chróścielewski, Warszawa 2018.

Zimmermann J., Aksjomaty postępowania administracyjnego, Warszawa 2017.

Zimmermann J., Kilka refleksji o nowelizacji kodeksu postępowania administracyjnego, „Państwo i Prawo" 2017, z. 8.

Zimmermann J., Ordynacja podatkowa. Komentarz. Postępowanie podatkowe, Toruń 1998.

\section{Streszczenie}

\section{Tomasz Bąkowski}

\section{Pod „brandem" k.p.a. i poza nim}

Sześćdziesiąta rocznica uchwalenia kodeksu postępowania administracyjnego staje się okazją do wielowątkowych refleksji oraz ocen tego obecnie najstarszego spośród obowiązującego w polskim systemie prawa kodeksów. W niniejszym opracowaniu skoncentrowano się na ewoluującym zakresie regulacji kodeksu postępowania administracyjnego. Jego zawartość już od pierwotnej wersji nie odpowiadała w pełni nadanej mu nazwie. Za sprawą kolejnych zmian przedmiotowy zakres regulacji kodeksu postępowania administracyjnego podlegał wielu interesującym przeobrażeniom. W artykule przedstawiono najważniejsze z nich, wskazując równocześnie na ich przyczyny i towarzyszące im okoliczności. Podjęto też próbę oceny trafności zarówno poszerzania, jak i uszczuplania zakresu kodeksowej regulacji.

\section{Summary}

\section{Tomasz Bąkowski}

\section{Under and Out of the CAP's Brand}

The $60^{\text {th }}$ anniversary of the adoption of the Code of Administrative Procedure (hereinafter: "CAP") is a good reason to reflect and evaluate the oldest of codes in force in the Polish legal system. This paper is focused on the changing content of the CAP. It has not entirely corresponded to its own name even at the moment of its creation. Due to subsequent amendments the subject of the CAP regulation has undergone interesting transformations. In this paper the most important amendments, their reasons and circumstances accompanying their implementation have been presented. The author has also attempted to assess the accuracy of both the extension and reduction of the scope of CAP regulation.

Słowa kluczowe: kodeks, postępowanie administracyjne, kodeks postępowania administracyjnego, przedmiot kodeksowej regulacji

Keywords: code, administrative proceedings, Code of Administrative Procedure, subject of the code regulation 